\title{
Dabigatran versus warfarin under standard or pharmacogenetic-guided management for the prevention of stroke and systemic thromboembolism in patients with atrial fibrillation: a cost/utility analysis using an analytic decision model
}

Léon Nshimyumukiza', Julie Duplantie, Mathieu Gagnon ${ }^{1}, X^{1}$ avier Douville², Diane Fournier², Carmen Lindsay ${ }^{3}$, Marc Parent ${ }^{3}$, Alain Milot ${ }^{3,4}$, Yves Giguère ${ }^{3,5}$, Christian Gagné ${ }^{2}$, François Rousseau ${ }^{3,5}$ and Daniel Reinharz ${ }^{*}$

\begin{abstract}
Background: Atrial fibrillation (AF) is the most common form of heart arrhythmia and a leading cause of stroke and systemic embolism. Chronic anticoagulation is recommended for preventing those complications. Our study aimed to compare the cost/utility (CU) of three main anticoagulation options: 1) standard warfarin dosing (SD-W) 2) warfarin dosage under the guidance of CYP2C9 and VKORC1 genotyping (GT-W) and 3) dabigatran $150 \mathrm{mg}$ twice a day.

Methods: A Markov state transition model was built to simulate the expected C/U of dabigatran, SD-W and GT-W anticoagulation therapy for the prevention of stroke and systemic thromboembolism in patients with atrial fibrillation over a period of 5 years under the perspective of the public health care system. Model inputs were derived from extensive literature search and government's data bases. Outcomes considered were the number of total major events (thromboembolic and hemorrhagic events), total costs in Canadian dollars (1CAD\$=1\$US), total quality-adjusted life years (QALYs), costs/QALYs and incremental costs/QALYs gained (ICUR).
\end{abstract}

Results: Raw base case results show that SD-W has the lowest C/U ratio. However, the dabigatran option might be considered as an alternative, as its cost per additional QALY gained compared to SD-W is CAD \$ 4765 , i.e. less than 50 000, the ICUR threshold generally accepted to adopt an intervention. At the same threshold, GT-W doesn't appear to be an alternative to SD-W. Our results were robust to one-way and multi-way sensitivity analyses.

Conclusion: SD-W has the lowest C/U ratio among the 3 options. However, dabigatran might be considered as an alternative. GT-W is not C/U and should not currently be recommended for the routine anticoagulotherapy management of AF patients.

Keywords: Atrial fibrillation, Simulation, Cost-utility, Dabigatran etexilate, Warfarin, Anticoagulation, CYP2C9, VKORC1

\footnotetext{
* Correspondence: Daniel.Reinharz@fmed.ulaval.ca

'Département de médecine sociale et préventive, Faculté de Médecine,

Université Laval, 1050, avenue de la Médecine, Québec, QC GIV OA6, Canada

Full list of author information is available at the end of the article
} 


\section{Introduction}

Atrial fibrillation (AF) is the most common form of heart arrhythmia. Its prevalence exceeds $2 \%$ in the general population of individuals who are 40 years old and more and increases with age from $0.1 \%$ in 50 years old patients to $10 \%-15 \%$ in those who are more than 80 years old [1]. The number of AF patients is expected to increase as the result of population ageing [1]. AF is the leading cause of stroke and is also associated with a high risk of systemic embolism [2,3]. Thus, long-term anticoagulation therapy is recommended in all patients with AF. Vitamin K antagonists such as warfarin are currently the most prescribed oral anticoagulants with, in the USA only, around 31 million prescriptions filled each year [4].

By depleting active vitamin $\mathrm{K}$, warfarin therapy reduces the risk of stroke by about 60 percent in patients with AF [2]. However, warfarin has a narrow therapeutic range and is not devoid of adverse reactions: hemorrhages or thromboses occur in 6 to $39 \%$ of patients annually and are mainly related to the effectiveness of anticoagulation [5-7].

Yet, there is a large inter-individual heterogeneity in the optimal warfarin dosage required to achieve a therapeutic effect (inter-patients variability varies by a factor of 20) [8-10]. This optimal dosage is defined as a 2 to 3 score in the international normalized ratio (INR) score of the prothrombin time, as a score below 2 increases the risk of thrombotic events and a score above 3 of hemorrhagic events. Maintaining patients in the therapeutic range is therefore of utmost importance. Close INR monitoring is needed to reduce the risk of bleeding and thromboembolism [8-10].

Inter-patient variability in plasma warfarin concentration is dependent on variables such as age, diet, drug interactions, and liver function but also on some genes that affect the metabolism of the drug [11]. The most important known genes in the pharmacokinetics of warfarin are CYP2C9 (the gene coding for cytochrome P450 2C9) and VKORC1 (a gene coding for the vitamin K epoxide reductase complex subunit). Genetic variation in these two genes account for approximately $30 \%$ to $50 \%$ of the variance in warfarin concentration between individuals $[9,10,12]$. Adjusting the first doses of warfarin under the guidance of CYP2C9 and VKORC1 alleles determination reduces the risk of bleeding and thromboembolic complications [13]. Indeed, the US Federal Drug Administration (FDA) suggested, in August 2007, to update the warfarin information sheet to include information on the possibility of CYP2C9 and VKORC1 pharmacogenetic testing [14].

Several new drugs have been developed recently that represent a new strategy in the fight against thromboembolism in FA patients. Dabigatran is the first of these new products and constitutes the main alternative to warfarin presently. Dabigatran exerts its anti-thrombotic effect by binding to thrombin, which prevents the conversion of fibrinogen to fibrin. It has been shown to be associated with a lower occurrence of systemic embolism and stroke than warfarin and does not require a close laboratory monitoring $[15,16]$. However, because of its higher price, some health authorities still consider dabigatran as an exception drug that requires an authorization prior to its prescription for patients covered by public health insurances.

Economic studies have shown that dabigatran is expected to be a $\mathrm{C} / \mathrm{U}$ option under an acceptability threshold of 50 000\$/QALY [17-22], while results on the comparison between warfarin standard dosing (SD-W) and warfarin genetic-guided dosing (GT-W) remain inconclusive [23-26]. Only one study has compared the 3 strategies (dabigatran $150 \mathrm{mg}, \mathrm{SD}-\mathrm{W}$ and GT-W). It concluded that dabigatran $150 \mathrm{mg}$ is a $\mathrm{C} / \mathrm{U}$ option, under the perspective of the acceptability threshold of $50000 \$ /$ QLY. However, this study did not consider all major events related to anticoagulation and used a time horizon poorly supported by data [21]. Our study was conducted to evaluate the expected $\mathrm{C} / \mathrm{U}$ of these anticoagulation options under the perspective of the public health care system in order to provide elements in support to the decision making process by health authorities.

\section{Methodology}

\section{Modeling and event probabilities}

A Markov state transition model was built to simulate the $\mathrm{C} / \mathrm{U}$ of anticoagulation therapy for a virtual population of 10000 individuals with a new diagnosis of AF under the perspective of the public health care system (Figure 1). The virtual population consisted of new AF patients with a mean age of 64 years $(\mathrm{sd} .=8)$, who never had a previous stroke and who didn't have a contraindication to anticoagulation therapy.

Outcomes considered were major hemorrhagic and thromboembolic events per 100 person-years, direct medical costs and quality-adjusted life-years (QALY). The model consists of daily cycles starting at the first day of anticoagulation treatment and ending 5 years later or at the death of an individual. The 5 years time horizon was chosen in order to take into account the chronicity of anticoagulation therapy in AF while avoiding to speculate about the long term effects of dabigatran.

Input parameters were retrieved from an extensive literature search of guidelines on anticoagulation in FA patients, and peer-reviewed published studies prioritized according to the following order: Quebec, other provinces of Canada, United States of America (USA), Europe and Australia.

The model begins by presenting the following three options: 1) SD-W; 2) GT-W; and 3) dabigatran $150 \mathrm{mg}$ twice per day. Dabigatran was chosen among the new oral anticoagulants because it is the first one that has been approved in Canada and the first one that has been 


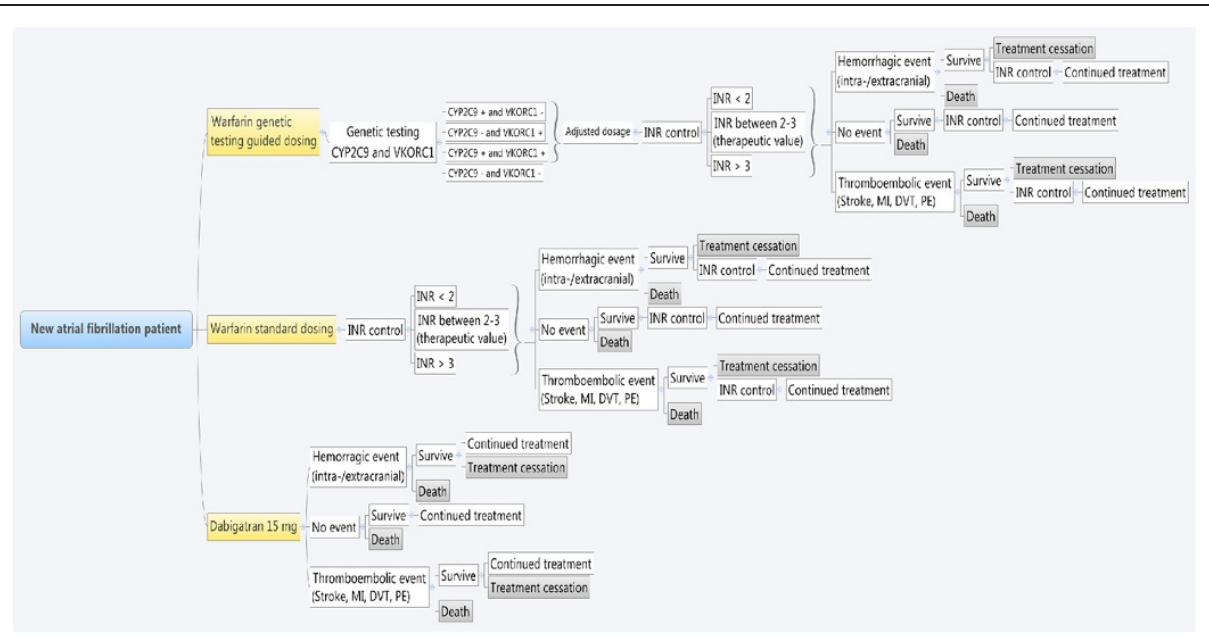

Figure 1 Markov state transition model.

included in drug lists of the Canadian provincial public insurance schemes.

In the warfarin options (SD-W and GT-W), treatment monitoring is performed by measuring the international normalized ratio (INR). INR may be below $(<2)$, within (between 2 and 3), or above ( $>3$ ) the therapeutic range. In the SD-W base case scenario, the time spent in each category (below, within and above) was based on the results of the RE-LY clinical trial comparing dabigatran and warfarin [16], while in the GT-W option, it was calculated using data from Anderson et al. 2007 [13]. We assumed that after one year $100 \%$ of individuals, whatever the warfarin group they belong to, had reached a stable maintenance dose [27]. The proportion of patient time spent in each INR category (below, within and above) was considered to be similar for both groups [27]. In the dabigatran option, it was assumed that no laboratory monitoring was required.

According to event probabilities [16,17,28,29], patients move into the Markov model through the following health states: no major event, major hemorrhagic event, major thromboembolic event, and death (Figure 2).

Major thromboembolic and hemorrhagic events were considered according to the definition of Fihn et al. [30]. Hemorrhages were classified into two categories: 1) intracranial (intracerebral and subdural hematoma) and 2) extracranial. We assumed that all extracranial hemorrhages were gastrointestinal as they constitute the majority of extracranial hemorrhages related to anticoagulant therapy regardless of the type of treatment

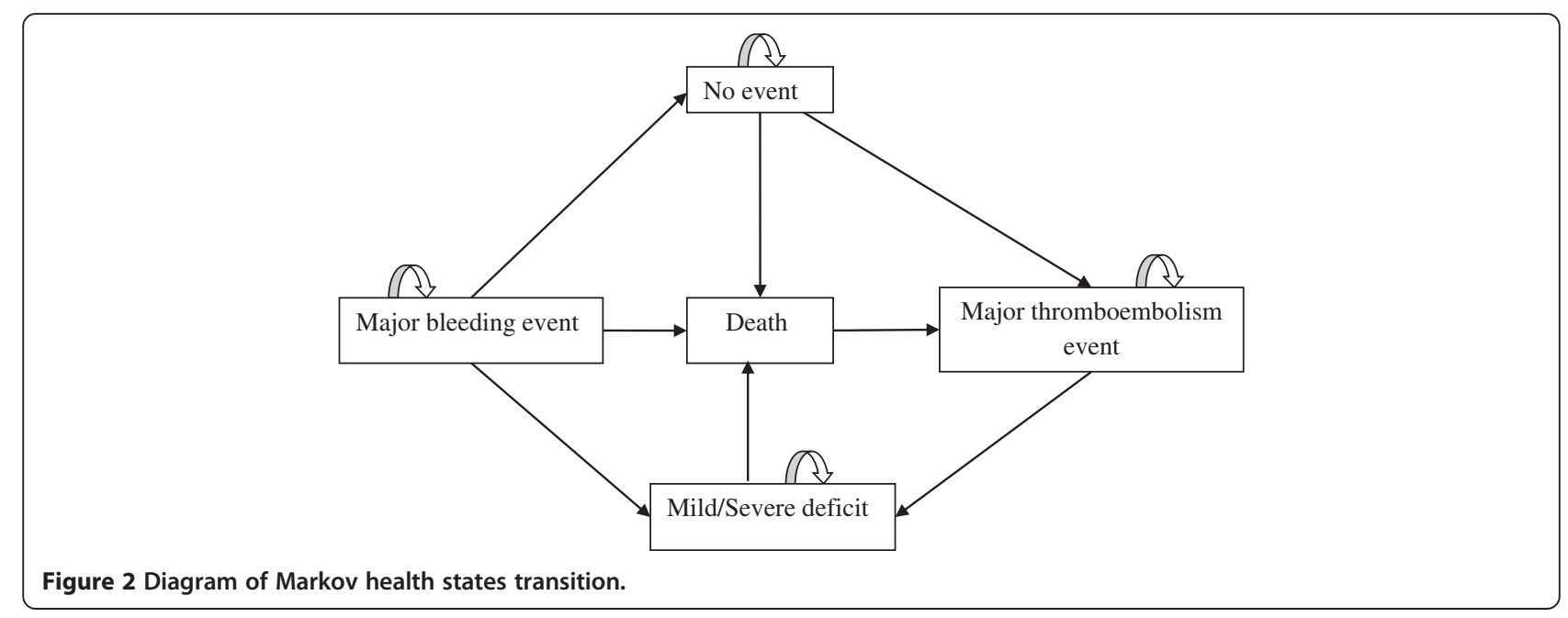


[28,31]. Major thromboembolic events considered were strokes, myocardial infarctions (MI), deep vein thromboses (DVT) and pulmonary embolisms (PE). Following the occurrence of a major event, the model assumed that an individual visits the emergency room and that he has a defined probability of being hospitalized for a short or a long period of time. In addition, the model considers the probability of survival and of death after each event as well as the probability to have mild or severe post-event sequelae (see Table 1). It also considers a complete cessation of anticoagulant therapy in case of intracranial hemorrhage and a one month cessation in case of gastrointestinal bleeding [26].

\section{Costs}

Costs included in the study are those of the public health care system. Only direct costs were estimated (Table 2).

Health services consumed along the course of an anticoagulation therapy relate primarily to services associated with prescription, warfarine monitoring and management of thromboembolic or hemorrhagic complications (deep vein thromboses, pulmonary embolisms, strokes, myocardial infarctions, intracranial, sub-dural and extracranial hemorrhages) [42,49-55] as well as the cost of follow-up in case of sequelae from a stroke or an intracranial hemorrhage.

The quantification of services consumed was based on the literature. In all cases, we considered for baseline values, recommendations by the Canadian guidelines on the management of thrombosis and anticoagulation $[42,49-55]$. For items not found in the guidelines, we used relevant economic studies published in peer-reviewed journals. Unit prices for services consumed were calculated from the administrative data of the Quebec public health care system. The lowest prices from the list of drugs covered by Quebec public healthcare insurance (Régie d'assurance maladie du Québec (RAMQ)) were used to estimate the cost of outpatient medication, to which were added $6 \%$ for wholesalers as well as the pharmacist fees paid by RAMQ. Diagnosis related-groups (DRG) data were used to calculate the average cost of hospitalization to which were added the physician fees paid by RAMQ. The ministry of health SIFO data bank was used to calculate activity center unit prices for ambulatory care. These prices were increased to reflect the contribution of support activity centers to clinical services, using the direct method [56]. The rate base used for these sources was the values of the 2010-2011 fiscal year.

\section{Utilities}

Utility scores used for each health states are presented in Table 1. They were retrieved from published studies $[21,47,48]$. Utility scores were then used to weight the time spent in each health state to produce QALYs.

\section{Simulation process and analysis}

Simulations were carried out on the SCHNAPS platform simulator $[57,58]$ that runs on the CLUMEQ network super computers. In the "individual sampling model (ISM)" simulation that was performed, each virtual individual is generated and has his own path in the simulation process. Simulations were repeated 1000 times with different virtual populations of 10000 individuals. However, each of the 1000 different virtual population generated was used for the three options compared. The principal outcome measured was the incremental cost-utility (ICUR) ratio calculated using the difference in average individual cost over the 1000 simulations divided by the difference in average QALYs. We considered the literature that proposes that an option can be accepted as cost-effective if its ICUR is CAD\$ 50 000/QALY or less [59]. An option was considered dominated if it was more costly and less effective (less QALY) in comparison to its alternative (strict dominance) or if it's incremental cost-effectiveness ratio was greater than that of the next, more effective, and more expensive alternative (extended dominance). All costs and QALY were discounted at a baseline annual rate of $3 \%$.

\section{Sensitivity analyses}

Univariate and multiway probabilistic sensitivity analyses were performed using the parameters that were foreseen as having a possible impact on the outcomes (Table 1). One way sensitivity analyses were performed to evaluate the eventual impact of each single parameter on the results. We tested the minimum and the maximum values (from the 95\% confidence intervals) for each of these variables. For the GT-W option, we tested several patient percentage times in therapeutic range (TTR) values in order to find the value for which GT-W would be costeffective compared to SD-W. Subsequently, multi-way probabilistic sensitivity analyses using Monte Carlo simulations were performed using a virtual population of 5000 individuals. We assumed that event probabilities and utility scores followed a beta distribution, that costs followed a gamma distribution while relative risks were assumed to have a log-normal distribution [60]. A C/U acceptability curve [61] was then produced from 1000 Monte Carlo iterations in order to better define the joint uncertainty of the parameters on $\mathrm{C} / \mathrm{U}$ ratios.

\section{Validation}

The Markov state decision model and the parameterization were validated by two experts (MA, PM) in genetics and anticoagulotherapy.

The simulation process was validated at each step to ensure that the data generated matched expected data. This consisted in verifying that the number of events (major bleedings and major thromboembolisms) 
Table 1 Model input parameters

Parameter
Baseline

e

Range for Distribution
sensitivity
analysis

\section{Event probabilities}

Percentage of INR time in therapeutic range (2-3) in warfarin usual standard dosing

Proportion of INR time range below therapeutic range $(<2)$

Percentage of increasing of TTR by warfarin pharmacogenetic guided dosing

Risk of major bleedings INR in therapeutic range

Relative risk of major bleedings INR above therapeutic range

Relative risk of major bleedings INR below therapeutic range

Relative risk of major hemorrhagic event dabigatran 150 mg vs warfarin
Major hemorrhagic events

(warfarin treatment)

Proportion major hemorrhagic events Dabigatran

$150 \mathrm{mg}$

Proportion intracranial
Proportion extracranial
$\%$ Intracranial
$\%$ Extracranial

Risk of major thromboembolic events INR in therapeutic range

Relative risk of major thromboembolic events INR above therapeutic range

Relative risk of major thromboembolic

Relative risk of major thromboembolic events dabigatran 150 vs warfarin

Major thromboembolic events (warfarin treatment)

Complications Major hemorrhagic event events INR below therapeutic range
Stroke and

systemic embolism

MI

PE

$\%$ Stroke

$\%$ Myocardial

infarctus (MI)

$\%$ Pulmonary

embolism (PE)

$\%$ Deep venous

intracranial No deficit

\section{Mild deficit}

Severe deficit

Death

Extracranial

Stroke

Death

Severe deficit

Mild deficit

No deficit

Death PE

Death DVT

Death IM thrombosis (DVT)

\begin{tabular}{|c|c|c|}
\hline $64 \%$ & $55-69 \%$ & Beta \\
\hline $54 \%$ & $45-60 \%$ & \\
\hline $7.3 \%$ & $0-30 \%$ & \\
\hline $1.4 \%$ & $0.9-2.3 \%$ & \\
\hline 1 & - & Fixed (reference) \\
\hline 4.7 & $3.57-10$ & Log-normal \\
\hline 0.93 & $0.81-1.07$ & \\
\hline $42 \%$ & $20-45 \%$ & Beta \\
\hline $58 \%$ & $55-80 \%$ & \\
\hline $12.6 \%$ & $6.3-13.4 \%$ & \\
\hline $90.4 \%$ & 86.6-93.7 & \\
\hline $2.4 \%$ & $1.2-4.9$ & \\
\hline 3.5 & $2.8-44$ & Log normal \\
\hline 0.9 & $0.6-1.3$ & \\
\hline 0.66 & $0.53-0.82$ & \\
\hline 1.38 & $1-1.91$ & \\
\hline 1.61 & $0.76-3.42$ & \\
\hline
\end{tabular}

$[16,17,28,29]$

[16]

$52.5 \%$

Fixed

[35]
$5 \%$

$8 \%$

nths 2 and 3 : $5.6 \%$ per month

$40.2 \%$

$42.5 \%$

$9.1 \%$

$12 \%$

$[38,40]$ 
Table 1 Model input parameters (Continued)

\begin{tabular}{|c|c|c|c|c|c|}
\hline \multirow[t]{2}{*}{ Treatment discontinuation after a major event } & Intracranial hemorrhage & \multicolumn{3}{|l|}{$\begin{array}{l}100 \% \text { during the } \\
\text { entire period }\end{array}$} & \multirow[t]{2}{*}{$\begin{array}{c}\text { [26] and expert } \\
\text { opinion }\end{array}$} \\
\hline & Extracranial hemorrhage & $\begin{array}{l}100 \% \text { during } \\
30 \text { days }\end{array}$ & & & \\
\hline \multicolumn{6}{|c|}{ Costs (CAD\$) } \\
\hline \multirow[t]{3}{*}{ Drug costs } & Dabigatran 150 mg & $3.20 /$ day & $1-5$ & Gamma & [41] \\
\hline & Warfarin $5 \mathrm{mg}$ & 0.074/day & $0.03-0.1$ & & \\
\hline & LMWH & $27.90 / 5$ days & - & Fixed & \\
\hline \multirow[t]{2}{*}{ INR monitoring (first year) } & SD-W & 8.06/month & $5-12$ & Gamma & {$[42]$} \\
\hline & GT-W & $5 /$ month & $2-8$ & & Assumption \\
\hline INR monitoring (subsequent years) & & 4.03/month & $2-6$ & & Assumption \\
\hline Genetic tests (CYP2C9 and VKORC1) & & 615 & $100-1000$ & & {$[43,44]$} \\
\hline \multirow[t]{11}{*}{ One-time event treatment costs } & $\begin{array}{l}\text { Ischemic stroke, } \\
\text { no deficit }\end{array}$ & 845 & $500-100$ & & {$[43,44]$} \\
\hline & $\begin{array}{l}\text { Ischemic stroke, } \\
\text { mild deficit }\end{array}$ & 23772 & $15000-40000$ & & [43-45] \\
\hline & $\begin{array}{l}\text { Ischemic stroke, } \\
\text { severe deficit }\end{array}$ & 42620 & $30000-60000$ & & [43-46] \\
\hline & $\begin{array}{l}\text { Intracranial hemorrhage } \\
(\mathrm{ICH}) \text {, non deficit }\end{array}$ & 1067 & $25000-50000$ & & [43-45] \\
\hline & ICH mild deficit & 21218 & $15000-25000$ & & {$[43-45]$} \\
\hline & ICH severe deficit & 36451 & $25000-50000$ & & {$[43-45]$} \\
\hline & Subdural hematoma & 31942 & $20000-45000$ & & {$[43-45]$} \\
\hline & $\begin{array}{l}\text { Extra cranial } \\
\text { hemorrhage }\end{array}$ & 8146 & $5000-12000$ & & {$[43,44]$} \\
\hline & DVT & 2576 & $1500-4000$ & & {$[43,44]$} \\
\hline & PE & 8799 & $5000-9000$ & & {$[43,45]$} \\
\hline & Ml & 7177 & $5000-15000$ & & {$[43,45]$} \\
\hline \multirow[t]{3}{*}{ Post-event cost } & $\begin{array}{l}\text { Severe disability } \\
\text { stroke//CH }\end{array}$ & 6259/month & $3000-10000$ & & {$[44-46]$} \\
\hline & $\begin{array}{l}\text { Mild disability } \\
\text { stroke//CH }\end{array}$ & $1855 /$ month & $1000-3000$ & & \\
\hline & \multicolumn{2}{|c|}{ Health utilities } & & & \\
\hline Warfarin no event & & 0.95 & $0.95-0.98$ & Beta & {$[21,47,48]$} \\
\hline Dabigatran no event & & 0.95 & $0.95-0.98$ & & {$[21,47,48]$} \\
\hline \multirow[t]{4}{*}{ Major bleeding } & No deficit & 0.51 & $0.15-0.60$ & & {$[21,47,48]$} \\
\hline & Mild deficit & 0.75 & $0.70-0.90$ & & \\
\hline & Severe deficit & 0.95 & $0.90-0.95$ & & \\
\hline & Extracranial & 0.80 & $0.75-0.85$ & & \\
\hline \multirow[t]{3}{*}{ Stroke } & No deficit & 0.95 & $0.90-0.95$ & & {$[21,47,48]$} \\
\hline & Minor & 0.75 & $0.70-0.90$ & & \\
\hline & Severe & 0.39 & $0.15-0.50$ & & \\
\hline $\mathrm{Ml}$ & & 0.84 & $0.80-0.90$ & & {$[21,47,48]$} \\
\hline PE & & 0.76 & $0.70-0.90$ & & {$[21,47,48]$} \\
\hline DVT & & 0.84 & $0.80-0.90$ & & {$[21,47,48]$} \\
\hline
\end{tabular}


Table 2 Base case results

\begin{tabular}{|c|c|c|c|c|c|c|c|c|}
\hline Option & $\begin{array}{l}\text { Major bleeds/100 } \\
\text { person-year }\end{array}$ & $\begin{array}{l}\text { Major TE/100 } \\
\text { person-year }\end{array}$ & $\begin{array}{l}\text { Cost/patient } \\
\text { (CAD \$) }\end{array}$ & QALY/patient & Cost/QALY & $\begin{array}{l}\Delta \text { Cost } \\
\text { CAD \$ }\end{array}$ & $\triangle \mathrm{QALY}$ & ICUR \\
\hline Standard warfarin ${ }^{*}$ dosage & 3.21 & 2.12 & 7289 & 3.5368 & 2061 & & & \\
\hline $\begin{array}{l}\text { Pharmacogenetic oriented } \\
\text { warfarin dosage }\end{array}$ & 3.09 & 2.126 & 7749 & 3.5453 & 2186 & 460 & 0.0085 & Dominated \\
\hline Dabigatran 150 mg BID & 2.872 & 1.813 & 8494 & 3.7897 & 2241 & 745 & 0.2444 & 4765 \\
\hline
\end{tabular}

*Less costly option.

corresponded to their predefined expected occurrence according to the literature [49-54].

\section{Ethical approval}

This project was approved by the Research Ethics Committee of Laval University.

\section{Results}

Base-case C/U results are presented in Table 2. SD-W has the lowest raw $\mathrm{C} / \mathrm{U}$ ratio. However, compared to SD-W, dabigatran increases QALYs by 0.2529 and increases the cost/individual by CAD\$ 1205 for an ICUR of 4765/QALY gained. It is therefore under the commonly proposed

Table 3 One-way Sensitivity analysis results

\begin{tabular}{|c|c|c|c|c|c|c|}
\hline Parameter & Option & Cost/patient & $\Delta$ cost & QALY & $\triangle$ QALY & ICUR \\
\hline \multirow[t]{3}{*}{$76.8 \%$ of Patient TTR with warfarin pharmacogenetic guided dosing } & Warfarin standard & 7289 & & 3,5358 & & \\
\hline & Warfarin genetic testing & 7611 & 322 & 3,6348 & 0,099 & 3253 \\
\hline & Dabigatran 150 & 8494 & 883 & 3,7897 & 0,1549 & 5700 \\
\hline \multirow[t]{3}{*}{ RR major hemorragic event dabigatran 150 vs warfarin $=0,81$} & warfarin standard & 7289 & & 3,5358 & & \\
\hline & warfarin genetic testing & 7749 & 460 & 3,5453 & 0,0085 & Dominated \\
\hline & Dabigatran 150 & 8142 & 393 & 3,8667 & 0,3214 & 2586 \\
\hline \multirow[t]{3}{*}{ RR major hemorragic event dabigatran 150 vs warfarin $=1,07$} & warfarin standard & 7289 & & 3,5358 & & \\
\hline & warfarin genetic testing & 7749 & 460 & 3,5453 & 0,0085 & Dominated \\
\hline & Dabigatran 150 & 8879 & 1130 & 3,695 & 0,1497 & 9987 \\
\hline \multirow[t]{3}{*}{ RR stroke dabigatran 150 VS warfarin $=0,82$} & warfarin standard & 7289 & & 3,5358 & & \\
\hline & warfarin genetic testing & 7749 & 460 & 3,5453 & 0,0085 & Dominated \\
\hline & Dabigatran 150 & 8765 & 1016 & 3,708 & 0,1627 & 8570 \\
\hline \multirow[t]{3}{*}{ RR stroke dabigatran 150 VS warfarin $=0,53$} & warfarin standard & 7289 & & 3,5358 & & \\
\hline & warfarin genetic testing & 7749 & 460 & 3,5453 & 0,0085 & Dominated \\
\hline & Dabigatran 150 & 8298 & 549 & 3,8113 & 0,2755 & 3660 \\
\hline \multirow[t]{3}{*}{ Cost genetic tests $=$ CAD $\$ 100$} & warfarin standard & 7289 & & 3,5368 & & \\
\hline & warfarin genetic testing & 7330 & 41 & 3.5453 & 0,0085 & Dominated \\
\hline & dabigatran 150 & 8494 & 1164 & 3.7897 & 0,2444 & 4765 \\
\hline \multirow[t]{3}{*}{ Cost genetic tests $=$ CAD $\$ 1000$} & warfarin standard & 7289 & & 3,5368 & & \\
\hline & warfarin genetic testing & 8050 & 41 & 3.5453 & 0,0085 & Dominated \\
\hline & dabigatran 150 & 8494 & 1164 & 3.7897 & 0,2444 & 4765 \\
\hline \multirow[t]{3}{*}{ Day cost of dabigatran $150=1 C A D \$$} & Dabigatran 150 & 5217 & & 3.7897 & & \\
\hline & Warfarin standard & 7289 & 2072 & 3.5368 & $-0,2444$ & Dominated \\
\hline & Warfarin genetic testing & 7749 & 460 & 3.5453 & $-0,0085$ & Dominated \\
\hline \multirow[t]{3}{*}{ Day cost of dabigatran $150=5 \$$} & Warfarin standard & 7289 & & 3,5368 & & \\
\hline & Warfarin genetic testing & 7749 & 460 & 3.5453 & 0,0085 & Dominated \\
\hline & Dabigatran 150 mg & 11182 & 1164 & 3.7897 & 0,2444 & 15393 \\
\hline \multirow[t]{3}{*}{ Utility score dabigatran without event $=0,98$} & warfarin standard & 7289 & & 3,5358 & & \\
\hline & warfarin genetic testing & 7749 & 460 & 3,5453 & 0,0085 & Dominated \\
\hline & Dabigatran 150 & 8494 & 745 & 3,902 & 0,3567 & 3290 \\
\hline
\end{tabular}


threshold of $50000 \$ / Q A L Y$. GT-W is not C/U. Compared to SD-W, it increases QALYs only by 0.0085 , and increases the cost/individual ratio by CAD $\$ 460$ for an ICER of 54 118/QALY gained. It is also dominated by dabigatran (extended dominance).

Sensitivity analyses show that the results were robust either in one-way or in probabilistic multiway sensitivity analyses. In one-way sensitivity analyses, dabigatran remains an alternative to the SD-W option if the threshold of 50000 /QALY is socially considered as acceptable [59]. Compared to SD-W, GT-W is not C/U except when this strategy allows patients to have an average of $76.8 \%$ of patient TTR, i.e. 20\% more than in the SD-W option in the first year (Table 3). This value was found as the threshold for GT-W to be cost-effective and the ICUR is then 3250/ QALY gained which is less than the acceptability threshold of 50000 CAD \$ [59].

In probabilistic multiway sensitivity analyses, dabigatran $150 \mathrm{mg}$ remains the most $\mathrm{C} / \mathrm{U}$ option. Compared to SD-W, it is dominant in $32 \%$ of iterations and cost-effective in 99.75\% of iterations if the ceiling ratio threshold is fixed at CAD\$ 50 000/QALY gained (Figure 3).

\section{Discussion}

In this study, we evaluated through a simulation model the expected cost-utility of three anticoagulation options namely SD-W, GT-W and dabigatran $150 \mathrm{mg}$ twice daily, over a 5 years' time horizon and under a public health care perspective. Our results show that the dabigatran option is the most $\mathrm{C} / \mathrm{U}$ option if the public health care system accepts to invest CAD \$4 800 per additional QALY gained. This amount is lower than the 50000 per QALY gained commonly proposed as the threshold to adopt an innovation in North-America [59]. Although our study has used a more complete model than several other $\mathrm{C} / \mathrm{E}$ analyses, its results are consistent with the literature [17-20,22]. Nevertheless, we don't know if the results could be generalized to all other NOACs as there is still a lack of data concerning the direct comparison between the different products on the market. Currently, only indirect comparisons exist on the efficacy and safety of the NOACs that show that they are effective compared to warfarin. Yet, when they are compared to each other, there is no difference in efficacy, although some differences in safety might exist [62,63].

The GT-W option was not cost/effective (if not dominated) compared to the two other options. This is in line with other studies that have compared warfarin treatments with or without genetic testing [23,25,26]. However, GT-W could be the most C/U option compared to $\mathrm{SD}-\mathrm{W}$ and dabigatran $150 \mathrm{mg}$, if the average patient time in the therapeutic range moves from $66.6 \%$ to $76.8 \%$ i.e. if it is $20 \%$ higher than in the SD-W option in the first year. However, this is a very ambitious objective to reach even in clinical trial conditions [13]. This result is close to that of You et al. [21] who showed that the GT-W option could become the most cost-effective option if the patient time in the therapeutic range was $>77 \%$.

This study has some limitations. First, the key input parameters (events probabilities, INR control) comparing dabigatran vs. SD-W or SD-W vs. GT-W were taken from one single randomized controlled clinical trial. This issue could have decreased the ICUR since the effectiveness of dabigatran or GT-W may be overestimated by controlled clinical trials compared to the situation in real life. Nevertheless, we have done extensive sensitivity analyses in order to handle this problem.

The second limitation is the complexity of mapping the reality. Some simplifications and assumptions were inevitable in the modeling approach. For example, we did not consider minor events (bleedings and thromboembolism)

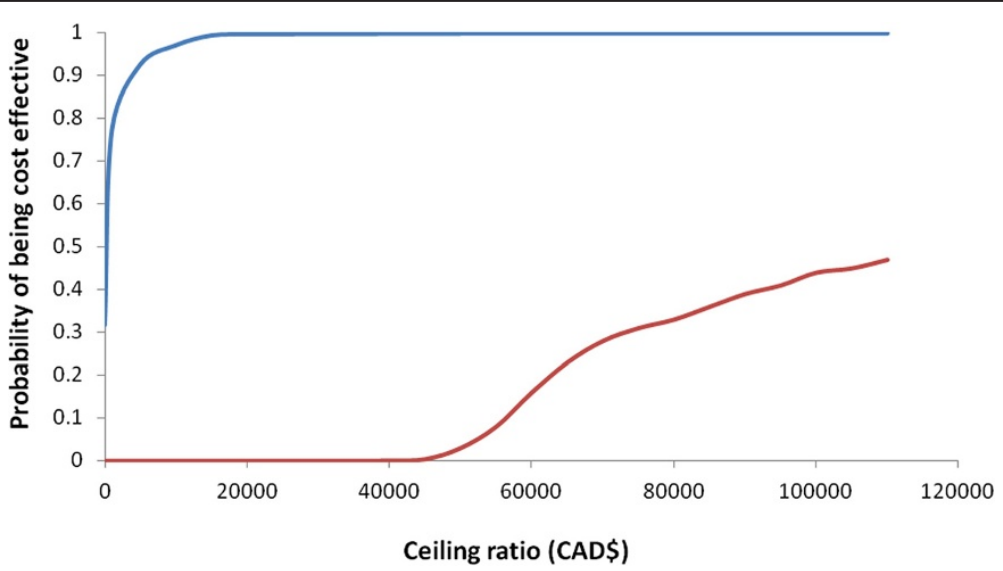

Figure 3 Cost-utility acceptability curves. Blue: The curve represents the probability of dabigatran to be cost-effective compared to warfarin standard dosing at various ceiling ratios thresholds. Red: The curve represents the probability of warfarin pharmacogenetic guided dosing to be cost-effective compared to warfarin standard dosing at various ceiling ratios thresholds. 
that occur with anticoagulation therapy. This issue could have increased the ICURs.

Thirdly, our model did not consider patients' adherence with medication in order to make a fairly comparison of the dabigatran option with the two others. Indeed, while longtime adherence for warfarin is available, there is still a lack of data on longtime adherence for dabigatran [64]. Taking into account the medication adherence would have led us to make assumptions about the adherence for dabigatran.

Finally, our model is limited by the consideration of only direct costs and one single perspective, i.e. the public healthcare perspective. The addition of the patients' perspective could increase the ICUR especially in the case of SD-W that might require time and travel expenses for INR control.

Despite these limitations, the results of this study suggest that dabigatran $150 \mathrm{mg}$ twice per day is a $\mathrm{C} / \mathrm{U}$ alternative to $\mathrm{SD}$-W. Its additional cost per QALY gained is considered as socially acceptable. GT-W is not C/U and should not now be recommended in routine management of warfarin anticoagulotheray in FA patients. However, our results produced in the Quebec/Canadian context (a quasi-exclusive public health care system) remain to be confirmed for other health care jurisdictions especially where the public system is not dominant.

\section{Competing interests}

The authors declare that they have no competing interests.

\section{Authors' contributions}

All authors: Conception, design, acquisition and validation of data. MG, XD, DF: computer simulations. NL, DR, YG, FR, CG, AM, MP: analysis and interpretation of results. NL, DR, JD: Drafting the article. NL, DR, FR, AM, YG, MP: Critically revising of the article. All authors approved the final version of article.

\section{Funding}

This work having led to this chapter was supported by a grant from the Canadian Institutes of Health Research (CIHR), and also in part by the APOGÉE-Net/CanGèneTest Research and Knowledge Network in Genetic health Services, funded by the Canadian Institutes for Health Research (www.cangenetest.org), (grant number ETG-92250), as well as by the "Chaire de recherche FRSQ/MSSS/CHUQ en évaluation des technologies et des pratiques de pointe en medicine de laboratoire" held by FR.

\section{Author details}

'Département de médecine sociale et préventive, Faculté de Médecine, Université Laval, 1050, avenue de la Médecine, Québec, QC GIV 0A6, Canada. 2Département de génie électrique, Faculté des Sciences et de génie, Université Laval, Québec, Québec, Canada. ${ }^{3}$ Centre de recherche du centre hospitalier universitaire de Québec (CRCHUQ), Faculté de Médecine, Université Laval, Québec, Québec, Canada. ${ }^{4}$ Département de médecine, faculté de Médecine, Université Laval, Québec, Québec, Canada. ${ }^{5}$ Département de biologie moléculaire, biochimie médicale et pathologie, Faculté de Médecine, Université Laval, Québec, Québec, Canada.

Received: 18 January 2013 Accepted: 16 July 2013

Published: 17 July 2013

\section{References}

1. Healey JS, Parkash R, Pollak T, Tsang T, Dorian P, CCS Atrial Fibrillation Guidelines Committee: Canadian cardiovascular society atrial fibrillation guidelines 2010: etiology and initial investigations. Can J Cardiol 2011, 27(1):31-37.
2. Hart RG, Pearce LA, Aguilar MI: Meta-analysis: anti-thrombotic therapy to prevent stroke in patients who have nonvalvular atrial fibrillation. Ann Intern Med 2007, 146(12):857-867.

3. Poli $D$, Antonucci $E$, Grifoni $E$, et al: Stroke risk in atrial fibrillation patients on warfarin: predictive ability of risk stratification schemes for primary and secondary prevention. Thrombo Haemost 2009, 101(2):367-372.

4. Wysowski DK, Nourjah P, Swartz L: Bleeding complications with warfarin use: a prevalent adverse effect resulting in regulatory action. Arch Intern Med 2007, 167(13):1414-1419.

5. Krynetskiy E, McDonell P: Building individualized medicine: prevention of adverse reactions to warfarin therapy. J Pharmacol Exp Ther 2007, 322(2):427-434.

6. Lip GYH, Wrigley BJ, Pisters R: Anticoagulation versus placebo for heart failure in sinus rhythm. Cochrane Database Syst Rev 2012(Issue 6):Art. No.: CD003336. doi:10.1002/14651858.CD003336.pub2.

7. Palareti G, Legnani C, Guazzaloca G, Lelia V, Cosmi B, Lunghi B, Marchetti G, Poli D, Pengo V, ad hoc Study Group of the Italian Federation of Anticoagulation Clinics*: Risks factors for highly unstable response to oral anticoagulation: a case-control study. Br J Haematol 2005, 129(1):72-78.

8. Adcock DM, Koftan C, Crisan D, Kiechle FL: Effect of polymorphisms in the cytochrome P450 CYP2C9 gene on warfarin anticoagulation. Arch Pathol Lab Med 2004, 128(12):1360-1363.

9. Wadelius M, Pirmohamed M: Pharmacogenetics of warfarin: current status and future challenges. Pharmacogenomics J 2007, 7(2):99-111.

10. Wadelius M, Chen LY, Eriksson N, Bumpstead S, Ghori J, Wadelius C, Bentley D, McGinnis R, Deloukas P: Association of warfarin dose with genes involved in its action and metabolism. Hum Genet 2007, 121(1):23-34.

11. Thomas FJ, Mcleod HL, Watters JW: Pharmacogenomics: the influence of genomic variation on drug response. Curr Top Med Chem 2004, 4(13):1399-1409.

12. Tan G-M, Wu E, Lam YY, Yan BP: Role of warfarin pharmacogenetic testing in clinical practice. Pharmacogenomics J 2010, 11(3):439-448.

13. Anderson JL, Horne BD, Stevens SM, Grove AS, Barton S, Nicholas ZP, Kahn SF, May HT, Samuelson KM, Muhlestein JB, Carlquist JF, Couma-Gen Investigators: Randomized trial of genotype-guided versus standard warfarin dosing in patients initiating oral anticoagulation. Circulation 2007, 116(22):2563-2570.

14. Gage BF, Lesko L: Pharmacogenetics of warfarin: regulatory, scientific, and clinical issues. J Thromb Thrombolysis 2007, 25(1):45-51.

15. Reddy P, Atay JK, Selbovitz LG, Connors JM, Piazza G, Block CC, Arpino PA, Berliner N, Hutter AM Jr, Fischer MA, Kuter D, Weitzman J, Sherwood GK, Almozlino A, Giugliano RP: Dabigatran: a review of clinical and pharmacoeconomic evidence. Crit Pathw Cardiol 2011, 10(3):117-127.

16. Connolly SJ, Ezekowitz MD, Yusuf S, Eikelboom J, Oldgren J, Parekh A, Pogue J, Reilly PA, Themeles E, Varrone J, Wang S, Alings M, Xavier D, Zhu J, Diaz R, Lewis BS, Darius H, Diener HC, Joyner CD, Wallentin L, RE-LY Steering Committee and Investigators: Dabigatran versus warfarin in patients with atrial fibrillation. N Engl J Med 2009, 361(12):1139-1151.

17. Freeman JV, Zhu RP, Owens DK, Garber AM, Hutton DW, Go AS, Wang PJ, Turakhia MP: Cost-effectiveness of dabigatran compared with warfarin for stroke prevention in atrial fibrillation. Ann Intern Med 2011, 154(1):1-11.

18. Kansal AR, Sorensen SV, Gani R, Robinson P, Pan F, Plumb JM, Cowie MR Cost-effectiveness of dabigatran etexilate for the prevention of stroke and systemic embolism in UK patients with atrial fibrillation. Heart 2012, 98(7):573-578.

19. Langkilde LK, Bergholdt AM, Overgaard M: Cost-effectiveness of dabigatran etexilate for stroke prevention in non-valvular atrial fibrillation. Applying RE-LY to clinical practice in Denmark. J Med Econ 2012, 15(4):695-703.

20. Sorensen SV, Kansal AR, Connolly S, Peng S, Linnehan J, Bradley-Kennedy C, Plumb JM: Cost-effectiveness of dabigatran etexilate for the prevention of stroke and systemic embolism in atrial fibrillation: a Canadian payer perspective. Thromb Haemost 2011, 105(5):908-919.

21. You JHS, Tsui KKN, Wong RSM, Cheng G: Cost-effectiveness of dabigatran versus genotype-guided management of warfarin therapy for stroke prevention in patients with atrial fibrillation. PLOS ONE 2012, 7(6):e39640. doi:10.1371/journal.pone.0039640.

22. Wouters $H$, Thijs $V$, Annemans $L$ : Cost-effectiveness of dabigatran etexilate in the prevention of stroke and systemic embolism in patients with atrial fibrillation in Belgium. J Med Econ 2013, 16(3):407-414.

23. Eckman MH, Rosan J, Greenberg SM, Gage BF: Cost-effectiveness of using pharmacogenetic information in warfarin dosing for patients with nonvalvular atrial fibrillation. Ann Intern Med 2009, 150(2):73-83. 
24. Meckley LM, Gudgeon JM, Anderson JL, Williams MS, Veenstra DL: A policy model to evaluate the benefits, risks and costs of warfarin pharmacogenomic testing. PharmacoEconomics 2010, 28(1):61-74.

25. Patrick AR, Avorn J, Choudhry NK: Cost-effectiveness of genotype-guided warfarin dosing for patients with atrial fibrillation. Circ Cardiovasc Qual Outcomes 2009, 2(5):429-436.

26. You JH, Tsui KK, Wong RS, Cheng G: Potential clinical and economic outcomes of CYP2C9 and VKORC1 genotype-guided dosing in patients starting warfarin therapy. Clin Pharmacol Ther 2009, 86(5):540-547.

27. Meckley LM, Wittkowsky AK, Rieder MJ, Rettie AE, Veenstra DL: An analysis of the relative effects of VKORC1 and CYP2C9 variants on anticoagulation related outcomes in warfarin-treated patients. Thromb Haemost 2008, 100(2):229-239.

28. Eikelboom JW, Wallantin L, Connolly SJ, Ezekowitz M, Healey JS, Oldgren J, Yang S, Alings M, Kaatz S, Hohnloser SH, Diener HC, Franzosi MG, Huber K, Reilly P, Varrone J, Yusuf S: Risk of bleeding with 2 doses of dabigatran compared with warfarin in older and younger patients with atrial fibrillation: an analysis of the randomized evaluation of long-term anticoagulant therapy (RE-LY) trial. Circulation 2011, 123(21):2363-2372

29. Schulman S, Kearon C, Kakkar AK, Mismetti P, Schellong S, Eriksson H, Baanstra D, Schnee J, Goldhaber SZ, RE-COVER Study Group: Dabigatran versus warfarin in the treatment of acute venous thromboembolism. N Engl J Med 2009, 361(24):2342-2352.

30. Fihn SD, MacDonell M, Martin D, Henikoff J, Vermes D, Kent D, White RH: Risk factors for complications of chronic anticoagulation. A multicenter study. Warfarin Optimized Outpatient Follow-up Study Group. Ann Intern Med 1993, 118(7):511-520.

31. Fang MC, Chen J, Rich MW: Atrial fibrillation in the elderly. Am J Med 2007, 120(6):481-487.

32. Oake N, Jennings A, Forster AJ, Fergusson D, Doucette S, van Walraven C: Anticoagulation intensity and outcomes among patients prescribed oral anticoagulant therapy: a systematic review and meta-analysis. CMAJ 2008, 179(3):235-244

33. Reynolds MW, Fahrback K, Hauch O, Wygant G, Estok R, Cella C, Nalysnyk L: Warfarin anticoagulation and outcomes in patients with atrial fibrillation: a systematic review and metaanalysis. Chest 2004, 126(6):1938-1945.

34. Lafata JE, Martin SA, Kaatz S, Ward RE: The cost-effectiveness of different management strategies for patients on chronic warfarin therapy. $J$ Gen Intern Med 2000, 15(1):31-37.

35. Connock M, Stevens C, Fry-Smith A, Jowett S, Fitzmaurice D, Moore D, Song F: Clinical effectiveness and cost-effectiveness of different models of managing long-term oral anticoagulation therapy: a systematic review and economic modelling. Health Technol Assess 2007, 11(38):iii-iv. ix-66.

36. Matchar DB, Jacobson A, Dolor R, Edson R, Uyeda L, Phibbs CS, Vertrees JE, Shih MC, Holodniy M, Lavori P, THINRS Executive Committee and Site Investigators: Effect of home testing of international normalized ratio on clinical events. N Engl J Med 2010, 363(17):1608-1620.

37. Hylek EM, Evans-Molina C, Shea C, Henault LE, Regan S: Major hemorrhage and tolerability of warfarin in the first year of therapy among elderly patients with atrial fibrillation. Circulation 2007, 115(21):2689-2696.

38. White R: The epidemiology of venous thromboembolism. Circulation 2003, 107(23 Suppl 1):14-18.

39. Goldhaber SZ, Visani L, De Rosa M: Acute pulmonary embolism: clinical outcomes in the International Cooperative Pulmonary Embolism Registry (ICOPER). Lancet 1999, 353(9162):1386-1389.

40. Cushman M, Psaty BM, Meilahn EN, Dobs AS, Kuller LH: Post-menopausal hormone therapy and concentrations of protein $C$ and antithrombin in elderly women. Br J Haematol 2001, 114(1):162-168.

41. Régie d'assurance maladie du Québec: Manuel des pharmaciens, Direction du service à la clientèle professionnelle. Québec. Québec: Gouvernement du Québec; 2011.

42. Parent M, Chrétien D, Plante S: Coût de revient du suivi de la warfarine en clinique d'anticoagulothérapie. Pharmactuel 2010, 43(4):232-236.

43. Régie d'assurance maladie du Québec: Manuel des médecins spécialistes, Direction du service à la clientèle professionnelle. Québec. Québec: RAMQ; 2011.

44. Ministère de la santé et des services sociaux: SIFO Système d'Information Financière et Opérationnelle:méthodologie, Direction de l'information. Québec: Gouvernement du Québec; 2011.

45. Ministère de la santé et des services sociaux: Banque de données APR-DRG (All Patient Refined Diagnosis Related Groups). Québec. Québec: Gouvernement du Québec; 2011.
46. Ministère de la santé et des services sociaux: Diem-Hébergement en soins de longue durée, Direction de la documentation. Québec. Québec: Gouvernement du Québec; 2010.

47. Gage BF, Cardinalli AB, Owens DK: The effect of stroke and stroke prophylaxis with aspirin or warfarin on quality of life. Arch Intern Med 1996, 156:1829-1836.

48. Sullivan PW, Arrant TW, Ellis SL, et al: The cost effectiveness of anticoagulation management services for patients with atrial fibrillation and at high risk of stroke in the US. PharmacoEconomics 2006, 24:1021-1033.

49. Snow V, Weiss KB, LeFevre M, McNamara R, Bass E, Green LA, Michl K, Owens DK, Susman J, Allen DI, Mottur-Pilson C, AAFP Panel on Atrial Fibrillation; ACP Panel on Atrial Fibrillation: Management of newly detected atrial fibrillation: a clinical practice guideline from the American Academy of Family Physicians and the American College of Physicians. Ann Intern Med 2003, 139(12):1009-1017.

50. Torbicki A, Perrier A, Konstantinides S, Agnelli G, Galiè N, Pruszczyk P, Bengel F, Brady AJ, Ferreira D, Janssens U, Klepetko W, Mayer E, Remy-Jardin M, Bassand JP, ESC Committee for Practice Guidelines (CPG): Guidelines on the diagnosis and management of acute pulmonary embolism: the Task Force for the Diagnosis and Management of Acute Pulmonary Embolism of the European Society of Cardiology (ESC). Eur Heart J 2008, 29(18):2276-2315.

51. Lindsay P, Baylay M, McDonald A, Graham ID, Warner G, Phillips S: Toward a more effective approach to stroke: Canadian best practice recommendations for stroke care. CMAJ 2008, 178(11):1418-1425.

52. Barkun A, Bardou M, Marshall JK, Nonvariceal Upper Gl Bleeding Consensus Conference Group: Consensus recommendations for managing patients with nonvariceal upper gastrointestinal bleeding. Ann Intern Med 2003, 139(10):843-857

53. Barkun A, Fallone CA, Chiba N, Fishman M, Flook N, Martin J, Rostom A, Taylor A, Nonvariceal Upper Gl Bleeding Consensus Conference Group: A Canadian clinical practice algorithm for the management of patients with nonvariceal upper gastrointestinal bleeding. Can J Gastroenterol 2004, 18(10):605-609.

54. Som R, Gossage JA, Crane A, Rowe PH: Surgical workload, risk factors and complications in patients on warfarin with gastrointestinal bleeding. Int J Surg 2010, 8(1):52-55.

55. Collège des Médecins du Québec et Ordre des pharmaciens du Québec: Lignes directrices-Anticoagulothérapie en milieu ambulatoire. Montréal (Québec): Collège des médecins du Québec et Ordre des pharmaciens du Québec; 2005

56. Drummond MF, Sculpher MJ, Torrance GW, O'Brien BJ, Stoddart GL: Methods for the economic evaluation of health care programmes. London: Oxford, Oxford University Press; 2005

57. Durand A, Gagné C, Nshimyumukiza L, Gagnon M, Rousseau F, Giguère Y, Reinharz D: Population-based simulation for public health: generic software infrastructure and its application to osteoporosis. IEEE Transactions on Systems, Man and Cybernetics, Part A: Systems and Humans 2012, 42(no 6):1396-1409.

58. Durand A, Gagné C, Gardner M-A, Rousseau F, Giguére Y: SCHNAPS: a generic population-based simulator for public health purposes. In Proceedings of the 2010 Summer Simulation Multiconference July 12-14. Ottawa, ON; Canada: Summer Computer simulation Conference (SCSC; 2010:182-189).

59. Menon D, Stafinski T: Health technology assessment in Canada: 20 years strong? Value Health 2009, 12(Suppl 2):S14-S19.

60. Briggs A, Claxton K, Sculpher M: Decision modelling for health economic evaluation. New York: Oxford University Press; 2006.

61. Sendi PP, Briggs AH: Affordability and cost-effectiveness: decision-making on the cost-effectiveness plane. Health Econ 2001, 10(7):675-680.

62. Mantha S, A.nsell J: An indirect comparison of dabigatran, rivaroxaban and apixaban for atrial fibrillation. Thromb Haemost 2012, 108(3):476-484

63. Harenberg J, Marx S, Diener HC, Lip GY, Marder VJ, Wehling M, Weiss C: Comparison of efficacy and safety of dabigatran, rivaroxaban and apixaban in patients with atrial fibrillation using network meta-analysis. Int Angiol 2012, 31(4):330-339.

64. Kopesky S: New anticoagulants for stroke prophylaxis in atrial fibrillation: assessing the impact on medication adherence. Am J Cardiovasc Drugs 2012, 12(5):287-294.

\section{doi:10.1186/1477-9560-11-14}

Cite this article as: Nshimyumukiza et al:: Dabigatran versus warfarin under standard or pharmacogenetic-guided management for the prevention of stroke and systemic thromboembolism in patients with atrial fibrillation: a cost/utility analysis using an analytic decision model. Thrombosis Journal 2013 11:14. 